Романченко I. С., д.військ.н., професор;

Можаровський В. М., к.військ.н.

Центральний науково-дослідний інститут Збройних Сил України, Київ

\title{
Математична модель визначення потрібної кількості знищених бойових засобів противника для досягнення заданої величини відверненого збитку своїх військ в операції тривалістю $T$ діб
}

\begin{abstract}
Резюме. У статті розкрито зміст однієї з математичних моделей, яка використовується під час обгрунтування раціонального (оптимального) бойового складу Збройних Сил України через величину відверненого збитку своїх військ в операції (бойових діях).
\end{abstract}

Ключові слова: модель, імовірність, бойові засоби, бойовий потенціал, втрати, відвернений збиток.

Постановка проблеми. Обгрунтування раціонального (оптимального) бойового складу Збройних Сил (далі - 3C) України здійснюється шляхом аналітичного моделювання, в основу якого покладено теорію відверненого збитку своїх військ (сил) в операції (бойових діях) [1]. Однією з моделей, які при цьому використовуються, $\epsilon$ математична модель визначення потрібної кількості знищених бойових засобів противника для досягнення заданої величини відверненого збитку своїх військ в операції тривалістю $T$ діб.

Аналіз останніх досліджень i публікацій. Висновки 3 аналізу існуючих методик обгрунтування бойового складу військ (сил) були викладені в інших публікаціях [2-5]. Зокрема, було встановлено, що математичні моделі, які використовуються в цих методиках, передбачають обчислення ймовірності ураження об' єктів противника в умовах, коли для ураження (знищення) такого об'єкта призначаються конкретні бойові засоби. При цьому, зазначені моделі враховують такі показники, як можливі (допустимі) втрати своїх військ та потрібні (задані) втрати військ противника [6-8].

На відміну від попередніх методик у дослідженні, яке проводиться авторами, використовуються математичні моделі [2-5], що грунтуються на теорії відверненого збитку своїх військ та дають змогу обчислити імовірність ураження (знищення) об'єктів противника за умови, коли обстріл того чи іншого об'скта (цілі) противника може здійснюватися всіма типами бойових засобів, які є у розпорядженні своїх військ (сил).

Мета статті. Викладення змісту математичної моделі визначення потрібної кількості знищених засобів противника для досягнення заданої величини відверненого збитку своїх військ в операції тривалістю $T$ діб.

Виклад основного матеріалу. Вважається, що для досягнення заданої величини коефіцієнта (рівня) боєздатності $\theta^{\text {вим }}$ стосовно своїх військ, яка зумовлюється одержанням певної величини відверненого збитку цих військ, не враховуючи способи бойового застосування, а також заходи всебічного забезпечення бойових дій своїх військ, необхідно знищити всіма своїми військами $\Delta N_{n p}$ бойових засобів противника за операцію тривалістю $T$ діб. Для цього потрібно мати до початку операції певну кількість $N_{0}^{\text {вим }} \geq N_{0}$ бойових засобів своїх військ, що, завдяки їхньому вогневому впливу на війська противника, дає змогу знизити середньодобові відносні втрати своїх військ 3 $\beta_{0}^{\prime}$ до $\beta_{n}$.

Зазначимо, що згідно наведеного вище, використання $P_{n p i}$ замість $\beta_{n p i}$ викликає необхідність уявити можливий алгоритм застосування розглядуваних сил та засобів своїх військ для знищення потрібної кількості $\Delta N_{n p i}$ бойових засобів $i$-го типу противника за період $T$ діб бойових дій 3 урахуванням бойових можливостей бойових засобів $j$-го типу своїх військ.

1. Один 3 таких алгоритмів полягає в тому, що розподіл бойових засобів своїх військ для знищення бойових засобів противника здійснюється таким чином, щоб кожна група $j-x$ засобів у кількості $N_{0 j}$ од. того чи іншого роду своїх військ, виходячи 3 особливостей їх 
застосування і можливостей, призначалася в основному для знищення цією групою 3 якоюсь імовірністю $P_{j i}$ відповідних $i-x$ засобів противника у кількості $N_{0 i n p}$ од. та навпаки, наприклад, як показано на рис. 1.

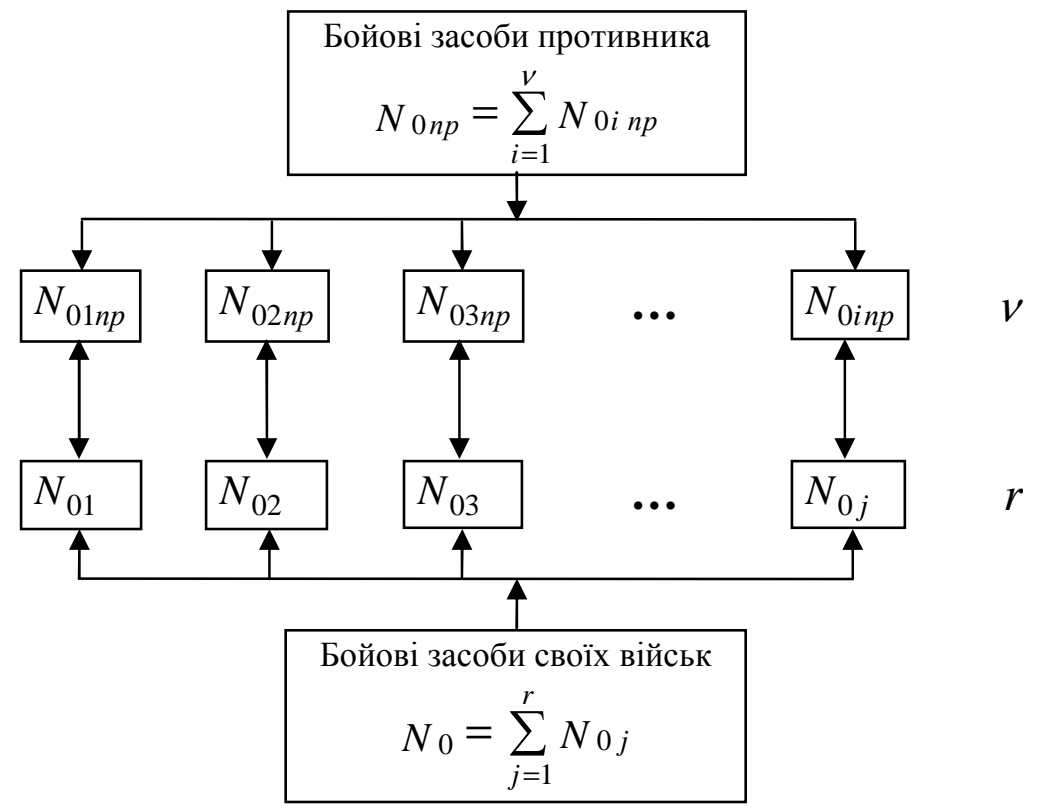

Рис. 1 Схема алгоритму застосування сил та засобів своїх військ для знищення потрібної кількості $\Delta N_{n p i}$ бойових засобів $i$-го типу противника за період $T$ діб

бойових дій з урахуванням бойових можливостей бойових засобів $j$-го типу своїх військ за умови, що бойовий засіб $j$-го типу військ діє тільки проти бойового засобу i-го типу противника

Це відповідає загальноприйнятому способу розподілу своїх сил та засобів під час планування операції (бою) та $\epsilon$ досить виправданим 3 погляду виключення випадків хаотичного застосування наявних сил та засобів своїх військ, більш раціонального їх використання, підвищення в цілому ефективності бойового застосування своїх військ. Наприклад, засоби протиповітряної оборони своїх військ призначаються в основному для знищення засобів повітряного нападу (ЗПН), протитанкові засоби - в основному для знищення танків та їм подібних засобів, а також окремих об'єктів; артилерія - для знищення точкових, лінійних та площинних об' єктів противника тощо.

Водночас це вимагає від штабів певного рівня підпорядкованості під час планування застосування того чи іншого роду військ ретельно аналізувати розвіддані щодо стану протиборчих військ, структури і складу їхніх засобів ураження. Це забезпечить у подальшому виправданий розподіл зусиль усіх своїх військ між відповідними складовими $N_{0 \text { inp }}$ БП $N_{0 n p}=\sum N_{0 i n p} \quad$ противника, виходячи 3 необхідності виконання поставлених бойових завдань.
Тоді за $T$ діб бойових дій, кількість $\Delta N_{n p 11}$, знищених з імовірністю $P_{11}$ бойових засобів першого типу противника із наявних $N_{0 n p}$ од. бойовими засобами першого типу своїх військ у складі $\Delta N_{01}$ од., дорівнює $\Delta N_{n p 11}=P_{11} \cdot N_{01 n p}$ тощо; кількість $\Delta N_{n p ~ j i}$, знищених з імовірністю $P_{j i}$ бойових засобів $i$ го типу противника із наявних $N_{0 i}$ од бойовими засобами своїх військ у складі $N_{0 j}$, враховуючи, що в даному випадку $i=j$, $\Delta N_{n p j i}=P_{j i} \cdot N_{0 i n p} \leq N_{0 i n p}$.

Отже, потрібна кількість знищених за період $T$ діб бойових дій бойових засобів усіх типів противника 3 наявних $N_{0 n p}=\sum N_{0 i n p}$ од. 3 урахуванням впливу на них із боку бойових засобів усіх типів протиборчих військ у складі $N_{0}$ од. для досягнення потрібного значення $\theta^{\text {вим }}$ буде дорівнювати $(i=j)$ : $\Delta N_{n p}=N_{0 n p} \cdot \beta_{n p} \cdot T=\sum_{i} N_{0 i n p} \cdot \beta_{n p i} \cdot T=$. $=\sum_{j} \Delta N_{n p j i}=\sum_{i} P_{j i} \cdot N_{0 i n p} \leq N_{0 n p}$

Однак такий спосіб розподілу своїх сил та засобів (рис. 1) є досить ідеалізованим і не 
завжди може бути реалізований під час бойових дій.

2. У реальних умовах бойових дій не виключено, що якийсь $j$-й бойовий засіб своїх військ буде знищувати 3 якоюсь імовірністю
$P_{j i}$ не тільки відповідний бойовий засіб противника, а й різні за типом його засоби ураження, що опиняться в зоні дій j-го засобу, як це показано на рис. 2.

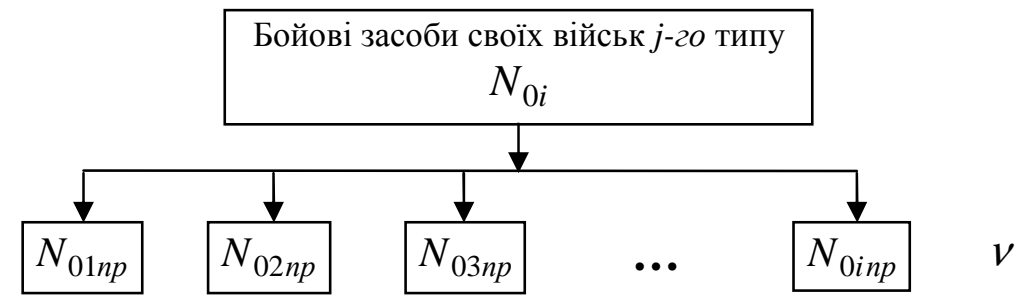

Бойові засоби противника $N_{0 n p}=\sum_{i} N_{0 i n p}$

Рис. 2 Приклад випадку, коли бойовий засіб $j$-го типу військ діє проти будь-яких типів бойових засобів противника

У цьому випадку засіб конкретного типу своїх військ діє на противника незалежно від дій засобів інших типів. Тоді за період $T$ діб бойових дій кількість $\Delta N_{n p 11}$ знищених з імовірністю $P_{11}$ бойових засобів першого типу противника із наявних од. бойовими засобами першого типу своїх військ у складі $N_{01}$ од. дорівнюватиме: $\Delta N_{n p 11}=P_{11} \cdot N_{01 n p} \quad$ кількість $\quad \Delta N_{n p 12}$, знищених 3 імовірністю $P_{12}$ бойових засобів другого типу противника із наявних $N_{02} n p$ од. бойовими засобами першого типу своїх військ у складі $N_{01}$ од. за період $T$ діб бойових дій дорівнюватиме: $\Delta N_{n p 12}=P_{12} \cdot N_{02 n p}$ тощо.

Аналогічно, кількість $\Delta N_{n p 1 i}$, знищених з імовірністю $P_{1 i}$ бойових засобів $i$-го типу противника із наявних $N_{0 i n p}$ од. бойовими засобами першого типу своїх війську складі $N_{01}$ од. за період $T$ діб бойових дій, дорівнює: $\Delta N_{n p 1 i}=P_{1 i} \cdot N_{0 i n p} ;$

загальна кількість знищених бойовими засобами першого типу своїх військ у складі $N_{01}$ од. військових формувань або бойових засобів усіх типів противника із наявних $N_{0 n p}=\sum_{i} N_{0 i n p}$ од. за період $T$ діб бойових дій: $\Delta N_{n p 1}=\sum_{i} N_{n p 1 i}=\sum_{i} P_{1 i} \cdot N_{0 i n p}$;

кількість знищених з імовірністю $P_{21}$ бойових засобів першого типу противника із наявних $N_{01 n p}$ од. бойовими засобами другого типу своїх військ у складі $N_{02}$ од. за період $T$ діб бойових дій: $\Delta N_{n p 21}=P_{21} \cdot N_{01 n p}$; кількість $\quad \Delta N_{n p 22}, \quad$ знищених 3 імовірністю $P_{22}$ бойових засобів другого типу противника із наявних $N_{02 n p}$ од. бойовими засобами другого типу своїх військ у складі $N_{02}$ од. за період $T$ діб бойових дій: $\Delta N_{n p 22}=P_{22} \cdot N_{02 n p}$ тощо;

аналогічно, кількість $\Delta N_{n p 2 i}$, знищених 3 імовірністю $P_{2 i}$ бойових засобів $i$-го типу противника із наявних $N_{0 i n p}$ од. бойовими засобами другого типу своїх військ у складі $N_{02}$ од. за період $T$ діб бойових дій складе: $\Delta N_{n p 2 i}=P_{2 i} \cdot N_{0 i n p} ;$

загальна кількість знищених бойовими засобами другого типу у складі $N_{02}$ од. своїх військ бойових засобів усіх типів противника із наявних $N_{0 n p}=\sum_{i} N_{0 i n p}$ од. за період $T$ діб бойових дій: $\quad \Delta N_{n p 2}=\sum_{i} N_{n p 2 i}=\sum_{i} P_{2 i} \cdot N_{0 i n p}$ тощо;

кількість $\Delta N_{n p \text { ji }}$ знищених 3 імовірністю $P_{j i}$ бойових засобів $i$-го типу противника із наявних $N_{0 i \text { пр }}$ од. $j$-ми бойовими засобами своїх військ у складі $N_{0 i}$ од. за період $T$ діб бойових дій дорівнює: $\Delta N_{n p ~ j i}=P_{j i} \cdot N_{0 i n p}$;

загальна кількість знищених $j$-ми бойовими засобами у складі $N_{0 j}$ од. своїх військ бойових засобів усіх типів противника із наявних $N_{0 n p}$ од. за період $T$ діб бойових дій: 
$\Delta N_{n p j}=\sum_{i} \Delta N_{n p j i}=\sum_{i} P_{j i} \cdot N_{0 n p i}$,

де $P_{j i}=\frac{\Delta N_{n p j i}}{N_{0 i n p}}-$ імовірність знищення $j$-ми

бойовими засобами своїх військ у складі $N_{0 j}$

од. в операції тривалістю $T$ діб хоча б одного бойового засобу $i$-го типу противника 3 наявних $N_{0 i \text { пр }}$ од.

Ця ймовірність виражається через деякі відомі 3 досвіду військ або одержані розрахунковим шляхом параметри 3 урахуванням залучуваної кількості сил та засобів протиборчих сторін.

Тоді потрібна кількість $\Delta N_{n p}$ Знищених бойових засобів $i$-го типу противника за період $T$ діб бойових дій 3 наявних $N_{0 i n p}$ од. $\mathrm{i} 3$ урахуванням впливу на них з боку бойових засобів усіх типів у складі $N_{0}$ од. протиборчих військ для

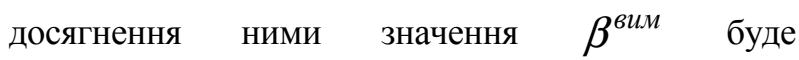
дорівнювати:

$$
\begin{gathered}
\Delta N_{n p i}=N_{0 i n p} \cdot \beta_{n p i} \cdot T=N_{0 i n p} \cdot P_{n p i}=\sum_{j} \Delta N_{n p j i}=\sum_{j} P_{j i} \cdot N_{0 i n p}= \\
=N_{0 i n p} \cdot \sum_{j} P_{j i} \leq N_{0 i n p}
\end{gathered}
$$

Звідси випливає, що ймовірність знищення силами та засобами усіх типів своїх військ в операції тривалістю $T$ діб одного бойового засобу $i$-го типу противника 3 наявних $N_{0 i ~ n p}$ од. за період $T$ діб бойових дій:

$P_{n p i}=\frac{\Delta N_{n p i}}{N_{0 i n p}}=\beta_{n p i} \cdot T=\sum_{j} P_{j i} \leq 1$,

де $P_{n p i}=\frac{\Delta N_{n p i}}{N_{0 i n p}}-$ імовірність знищення силами та засобами усіх типів своїх військ у складі $N_{0}$ од. в операції тривалістю $T$ діб одного бойового засобу $i$-го типу противника 3 наявних $N_{0 i \text { np }}$ од.

Із (2) маємо потрібні середньодобові за період $T$ діб бойових дій відносні втрати бойових засобів $i$-го типу противника внаслідок впливу на них 3 боку усіх бойових засобів

$$
\begin{gathered}
\Delta N_{n p}=N_{o n p} \cdot \beta_{n p} \cdot T=\sum_{i} \Delta N_{n p i}=\sum_{i} \beta_{n p i} \cdot N_{0 i n p} \cdot T=\sum_{i} P_{n p i} \cdot N_{0 i n p}= \\
=\sum_{i} \sum_{j} \Delta N_{n p i j}=\sum_{i} \sum_{j} P_{n p i j} \cdot N_{0 i n p}=P_{n p} \cdot N_{0 n p} \leq N_{0 n p}
\end{gathered},
$$

де, подібно до (2), імовірність знищення бойовими засобами усіх типів своїх військ у складі $N_{0}$ од. одного бойового засобу противника з наявних $N_{0 n p}$ од. за період $T$ діб бойових дій $-P_{n p i}=\frac{\Delta N_{n p}}{N_{0 n p}}=\beta_{n p} \cdot T$.

Такий порядок розподілу зусиль своїх військ забезпечить певний успіх в операції (бою), оскільки 3 використанням j-го засобу будуть знищені ще й додаткові, крім раніше визначених, засоби ураження противника, то це протиборчих військ для досягнення ними значення $\theta^{\text {вим }}$ :

$\beta_{n p i}=\frac{\Delta N_{n p i}}{T \cdot N_{0 i n p}}=\frac{P_{n p i}}{T}$.

через $P_{n p i}$, яке, в свою чергу, залежить від $P_{j i}(2)$.

Потрібна кількість знищених за період $T$ діб бойових дій бойових засобів усіх типів 3 наявних $N_{0 i n p}=\sum_{i} N_{0 i n p}$ од. противника 3 урахуванням впливу на них 3 боку бойових засобів усіх типів протиборчих військ у початковому складі $N_{0}$ од. для досягнення потрібного значення $\theta^{\text {вим }}$ :

тільки підвищить ефективність застосування своїх військ.

3. Зауважимо, що згідно (2) значення $P_{n p i}=\frac{\Delta N_{n p i}}{N_{0 i n p}}=\sum_{j} P_{j i} \leq 1$

передбачає

несумісність подій, кожна 3 яких пов'язана із знищенням 3 імовірністю $P_{j i}$ силами та засобами $j$-го типу своїх військ бойових засобів будь-якого типу противника у складі $N_{0 i n p}$ од., при цьому знищення цих засобів противника здійснюється роздільно у часі кожним бойовим засобом $j$-го типу своїх військ. У загальному ж 
випадку ці події можуть бути сумісні, тобто знищення засобів противника бойовими засобами j-го типу своїх військ може здійснюватися у часі сумісно, коли ті чи інші бойові засоби своїх військ можуть діяти по одному й тому самому, $i$-мy, засобу противника.

Такий алгоритм застосування своїх сил та засобів усіх типів може бути відображений на рис. 3 , коли очікується, що результатом їхніх дій буде знищення потрібної кількості $\Delta N_{n p i}$ сил та засобів $i$-го типу противника з імовірністю $P_{n p} i$ за впливу на них з боку $j$ - $x$ бойових засобів своїх військ в операції тривалістю $T$ діб та знищення цими засобами 3 імовірністю $P_{j i}$ хоча б одного бойового засобу $i$-го типу противника $з$ наявних $N_{0 i \text { пр }}$ од.

Бойові засоби $j$-го типу своїх військ з імовірністю знищення $P_{j i}$ бойових засобів j-го типу противника

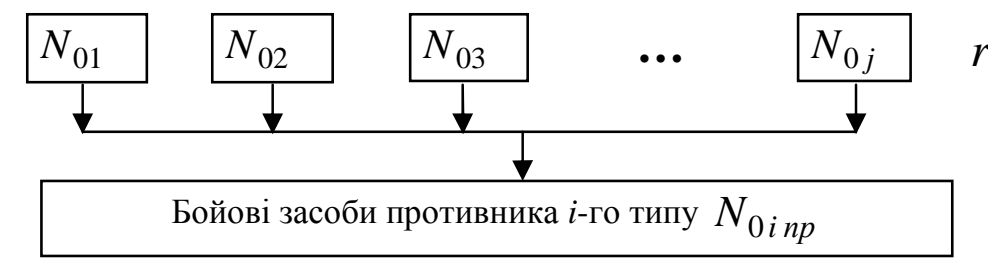

\section{Рис. 3 Алгоритм застосування своїх сил та засобів усіх типів, коли діють проти} бойового засобу $i$-го типу противника

У цьому випадку ймовірність $P_{n p i}$ знищення силами та засобами всіх типів своїх військ бойових засобів $i$-го типу противника за операцію тривалістю $T$ діб буде теж виражатися через імовірність $P_{j i}$, але, на відміну від (2), іншим способом, ураховуючи можливу сумісність розглядуваних подій.

Дійсно, згідно рис. 3, імовірність $P_{n p i}$ може обчислюватися в загальному випадку як імовірність суми $r(j=\overline{1, r})$ сумісних подій, кожна з яких пов' язана з внеском $P_{j i}$ бойових засобів $j$-го типу своїх військ у знищення бойових засобів $i$-го типу противника у складі $N_{0 i n p}$ од.

Наприклад, при $j=\overline{1, r}=\overline{1,4}$, ймовірність знищення всіма силами та засобами своїх військ бойових засобів $i$-го типу противника за операцію тривалістю $T$ діб під час впливу на них сил та засобів усіх типів протиборчих військ 3 урахуванням того, що кількість $N_{0 j}$ од. засобів $j$-го типу характеризується ймовірністю знищення $P_{j i}$ хоча б одного бойового засобу $i$-го типу противника з наявних $N_{0 i n p}$ од., буде, як відомо, дорівнювати:

$$
\begin{aligned}
& P_{n p_{i}}=P_{1 i} \cdot\left(1-P_{2 i}\right) \cdot\left(1-P_{3 i}\right) \cdot\left(1-P_{4 i}\right)+P_{2 i} \cdot\left(1-P_{1 i}\right) \cdot\left(1-P_{3 i}\right) \cdot\left(1-P_{4 i}\right)+ \\
& +P_{3 i} \cdot\left(1-P_{1 i}\right) \cdot\left(1-P_{2 i}\right) \cdot\left(1-P_{4 i}\right)+P_{4 i} \cdot\left(1-P_{1 i}\right) \cdot\left(1-P_{2 i}\right) \cdot\left(1-P_{3 i}\right)+ \\
& \quad+P_{1 i} \cdot P_{2 i} \cdot\left(1-P_{3 i}\right) \cdot\left(1-P_{4 i}\right)+P_{1 i} \cdot P_{3 i} \cdot\left(1-P_{2 i}\right) \cdot\left(1-P_{4 i}\right)+ \\
& \quad+P_{1 i} \cdot P_{4 i} \cdot\left(1-P_{2 i}\right) \cdot\left(1-P_{3 i}\right)+P_{2 i} \cdot P_{3 i} \cdot\left(1-P_{1 i}\right) \cdot\left(1-P_{4 i}\right)+ \\
& \quad+P_{2 i} \cdot P_{4 i} \cdot\left(1-P_{1 i}\right) \cdot\left(1-P_{3 i}\right)+P_{3 i} \cdot P_{4 i} \cdot\left(1-P_{1 i}\right) \cdot\left(1-P_{2 i}\right)+ \\
& \quad+P_{1 i} \cdot P_{2 i} \cdot P_{3 i} \cdot\left(1-P_{4 i}\right)+P_{1 i} \cdot P_{2 i} \cdot P_{4 i} \cdot\left(1-P_{3 i}\right)+ \\
& +P_{1 i} \cdot P_{3 i} \cdot P_{4 i} \cdot\left(1-P_{2 i}\right)+P_{2 i} \cdot P_{3 i} \cdot P_{4 i} \cdot\left(1-P_{1 i}\right)+P_{1 i} \cdot P_{2 i} \cdot P_{3 i} \cdot P_{4 i}= \\
& \quad=P_{1 i}+P_{2 i}+P_{3 i}+P_{4 i}-P_{1 i} \cdot P_{2 i}-P_{1 i} \cdot P_{3 i}-P_{1 i} \cdot P_{4 i}- \\
& \quad-P_{2 i} \cdot P_{3 i}-P_{2 i} \cdot P_{4 i}-P_{3 i} \cdot P_{4 i}+P_{1 i} \cdot P_{2 i} \cdot P_{3 i}+P_{1 i} \cdot P_{2 i} \cdot P_{4 i}+ \\
& \quad+P_{1_{i}} \cdot P_{3 i} \cdot P_{4 i}+P_{2 i} \cdot P_{3 i} \cdot P_{4 i}-P_{1_{i}} \cdot P_{2 i} \cdot P_{3 i} \cdot P_{4 i}= \\
& =\sum_{j} P_{j i}-\left(P_{1_{i}} \cdot P_{2 i}+P_{1_{i}} \cdot P_{3 i}+P_{1_{i}} \cdot P_{4 i}+P_{2 i} \cdot P_{3 i}+P_{2 i} \cdot P_{4 i}+P_{3 i} \cdot P_{4 i}\right)+ \\
& +\left(P_{1_{i}} \cdot P_{2 i} \cdot P_{3 i}+P_{1_{i}} \cdot P_{2 i} \cdot P_{4 i}+P_{1_{i}} \cdot P_{3 i} \cdot P_{4 i}+P_{2 i} \cdot P_{3 i} \cdot P_{4 i}\right)-P_{1_{i}} \cdot P_{2 i} \cdot P_{3 i} \cdot P_{4 i} \leq 1
\end{aligned}
$$


де $P_{j i}=\frac{\Delta N_{n p} j i}{N_{0 i n p}}-$ імовірність знищення $j$-ми бойовими засобами своїх військ у складі $N_{0 j}$ од. в операції тривалістю $T$ діб хоча б одного бойового засобу $i$-го типу противника 3 наявних $N_{0 i \text { np }}$ од.

Як бачимо з (1), значення

$P_{n p_{i}}=\frac{\Delta N_{n p i}}{N_{0 i n p}}=\frac{\sum_{j} \Delta N_{n p j i}}{N_{0 i n p}}=\frac{\sum_{j} P_{j i} \cdot N_{0 i n p}}{N_{0 i n p}} \leq 1$

не перевищує 1 за будь-яких величин $0 \leq P_{j i} \leq 1$.

У загальному ж випадку, на відміну від (5),

$P_{n p_{i}}=P_{c} \cdot\left(\sum_{j=1}^{r} A_{j i}\right)=f\left(P_{j i}\right)$,

де $P_{c} \cdot\left(\sum_{j=1}^{r} A_{j i}\right)$ - імовірність суми сумісних

подій $A_{j i}$, кожна 3 яких пов'язана 3 можливістю знищення $j$-ми бойовими засобами своїх військ 3 імовірністю $P_{j i}$ бойових засобів противника $i$-го типу 3 наявних $N_{0 i n p}$ од. за операцію тривалістю $T$ діб.

Імовірність $P_{c}=P_{n p i}$ (5) визначається знакопереміжним рядком $3 r$ членів ряду, кожний з яких містить суму можливих добутків елементів $P_{j i}(j=\overline{1, r}, i=\overline{1, v})$ по $n=1,2,3$, $4, \ldots, r$.

При цьому кількість $n$ добутків елементів $P_{j i}$ у кожному члені ряду визначається через число сполучень $C_{r}^{n}$ із $r$ до $n$, де $n=1,2,3,4$, $\ldots, r: C_{r}^{n}=\frac{r !}{n ! \cdot(r-n) !}$.

Зазначимо також, що стосовно (5) можна розглянути подію $\left(1-P_{1 i}\right) \cdot\left(1-P_{2 i}\right) \cdot\left(1-P_{3 i}\right) \cdot\left(1-P_{4 i}\right)$, яка сумісно 3 подіями в (5) створює повну групу несумісних подій, імовірність якої дорівнює 1. У цьому випадку можна вважати, що ймовірність незнищення $\left(1-P_{n p i}\right)$ усіма силами та засобами своїх військ бойових засобів $i$-го типу противника за операцію тривалістю $T$ діб під час впливу на них бойових засобів усіх типів протиборчих військ буде дорівнювати:

$$
1-P_{n p_{i}}=\left(1-P_{1 i}\right) \cdot\left(1-P_{2 i}\right) \cdot\left(1-P_{3 i}\right) \cdot\left(1-P_{4 i}\right),
$$

звідки $P_{n p_{i}}=1-\left(1-P_{1 i}\right) \cdot\left(1-P_{2 i}\right) \cdot\left(1-P_{3 i}\right) \cdot\left(1-P_{4 i}\right)$, або у більш загальному випадку для розрахунку $P_{n p i}$ поряд з (5) можна використовувати й таку залежність:

$$
\begin{aligned}
P_{n p i}= & 1-\left(1-P_{1 i}\right) \cdot\left(1-P_{2 i}\right) \cdot\left(1-P_{3 i}\right) \cdot\left(1-P_{4 i}\right) \cdot \ldots \cdot\left(1-P_{j i}\right) \cdot \ldots= \\
& =1-\prod_{j=1}^{r}\left(1-P_{j i}\right)=P_{c} \cdot\left(\sum_{j=1}^{r} A_{j i}\right)=f\left(P_{j i}\right)
\end{aligned}
$$

4. Як бачимо, розглянутий алгоритм застосування своїх сил та засобів усіх типів згідно рис. 3 містить більше можливих варіантів використання своїх сил та засобів у порівнянні $з$ подібним алгоритмом (рис. 2). Про це свідчить і те, що розрахунок імовірності $P_{n p i}=\sum_{j} P_{j i} \quad$ згідно (2) $є$ частковим випадком розрахунку ймовірності $P_{n p i}$ згідно (5), (6).
Тому в подальшому потрібна кількість $\Delta N_{n p i j}$ знищених бойових засобів $i$-го типу противника за період $T$ бойових дій з наявних $N_{0 i n p}$ од. та 3 урахуванням впливу на них 3 боку бойових засобів усіх типів у складі $N_{0}$ од. протиборчих військ для досягнення ними значення $\theta^{\text {вим }}$, на відміну від (1), буде обчислюватися таким чином:

$$
\Delta N_{n p i}=N_{0 i n p} \cdot \beta_{n p i} \cdot T=N_{0 i n p} \cdot P_{n p i}=N_{0 i n p} \cdot\left[1-\prod_{j=1}^{r}\left(1-P_{j i}\right)\right]=
$$




$$
\begin{aligned}
& =N_{0 i n p} \cdot\left[1-\prod_{j=1}^{r} e^{-\frac{R_{1 j i} \cdot n_{j i} \cdot N_{0 j}^{\text {Bum }} \cdot\left(1-\beta_{n j}\right)^{T}}{N_{0 i n p} \cdot\left(1-\beta_{n p i}\right)^{T}}}\right]= \\
& =N_{0 i n p} \cdot\left(1-e^{-\frac{1}{N_{0 i n p} \cdot\left(1-\frac{P_{n p i}}{T}\right)} \cdot \sum_{j=1}^{r} R_{1 j i} \cdot n_{j i} \cdot N_{0 j p}^{\text {sum }} \cdot\left(1-\beta_{n j}\right)^{T}}\right),
\end{aligned}
$$

а загальна кількість $\Delta N_{n p}$, на відміну від (4), 3 урахуванням того, що

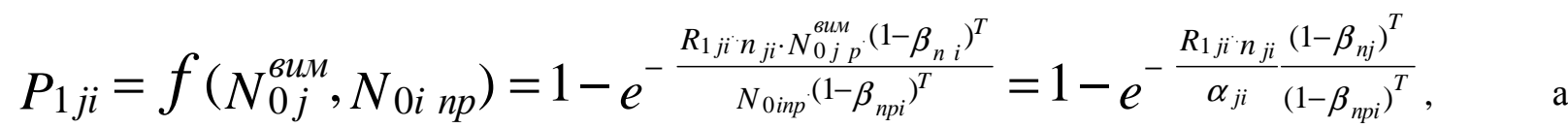

$$
\begin{aligned}
& \Delta N_{n p}=N_{0 n p} \cdot \beta_{n p} \cdot T=\sum_{i} N_{n p i}=\sum_{i} \beta_{n p i} \cdot N_{0 i n p} \cdot T=\sum_{i} P_{n p i} \cdot N_{0 i n p}=P_{n p} \cdot N_{0 n p} \leq N_{0 n p}, \quad \text { a }
\end{aligned}
$$

також (6), та втрат своїх військ і противника, противника повинна бути не меншою від завданих за період $T$ діб бойових дій з'єднань
(частин, підрозділів) або бойових засобів усіх$$
\text { типів } 3 \text { наявних } \Delta N_{0 n p}=\sum_{i} N_{0 i n p} \text { од. }
$$

$$
\begin{aligned}
& \Delta N_{n p}=\sum_{i} \Delta N_{n p i}=N_{0 n p} \cdot \beta_{n p} \cdot T=\sum_{i} \beta_{n p i} \cdot N_{0 i n p} \cdot T=N_{0 n p} \cdot P_{n p}=\sum_{i} \Delta N_{n p i}= \\
& =\sum_{i} P_{n p i} \cdot N_{0 i n p}=\sum_{i} N_{0 i n p} \cdot\left[1-\prod_{j=1}^{r}\left(1-P_{j i}\right)\right]=
\end{aligned}
$$

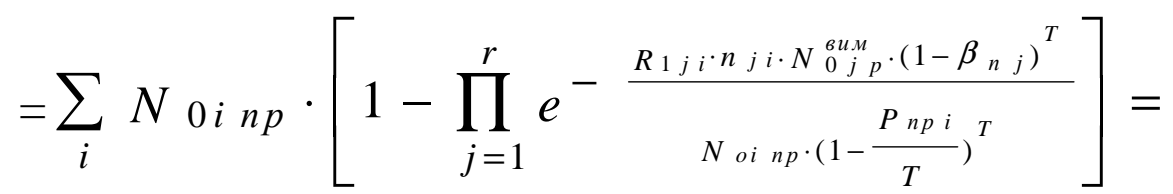

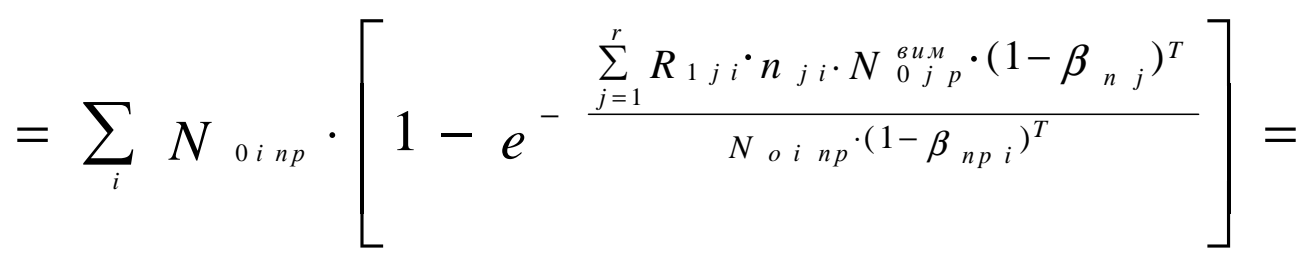

$$
\begin{aligned}
& =N_{0 n p}-\sum_{i} N_{0 i n p} \cdot e^{-\frac{\sum_{j=1}^{r} R_{1 j i} \cdot n_{j i} \cdot N_{0 j p}^{s u n} \cdot\left(1-\beta_{n j}\right)^{T}}{N_{0 i n p} \cdot\left(1-\beta_{n p i}\right)^{T}}} \geq \Delta N_{n p}^{\text {вun }}=N_{0 n p} \cdot \frac{\delta \Pi}{N_{0} \cdot \beta_{0}^{\prime} \cdot T}= \\
& =N_{0 n p} \cdot\left(1-\frac{1-\theta^{\text {вим }}}{\beta_{0}^{\prime} \cdot T}\right),
\end{aligned}
$$

де $P_{n p i}$ - імовірність знищення усіма силами усіх типів протиборчих військ визначається та засобами своїх військ бойових засобів $i$-го згідно (5), (6) з урахуванням $P_{1 j i}$ : типу противника за операцію тривалістю $T$ діб під час сумісного впливу на них сил та засобів

$$
\begin{aligned}
& P_{n p i}=1-\prod_{j=1}^{r}\left(1-P_{j i}\right)=1-\prod_{j=1}^{r} e^{-\frac{R_{1 j i} \cdot n_{j i} \cdot N_{0 j}^{\text {sun }} \cdot\left(1-\beta_{n j}\right)^{T}}{N_{0 i n p} \cdot\left(1-\beta_{n p i}\right)^{T}}}= \\
& =1-e^{-\frac{1}{N_{0 i n p} \cdot\left(1-\beta_{n p i}\right)^{T}} \cdot \sum_{j=1}^{r} R_{1 j i} \cdot n_{j i} \cdot N_{0 j}^{\text {suu }} \cdot\left(1-\beta_{n j}\right)^{T}},
\end{aligned}
$$

тоді 


$$
1-P_{n p i} \cdot e^{-\frac{1}{N_{0 i n p} \cdot\left(1-\beta_{n p i}\right)^{T}} \cdot \sum_{j=1}^{r} R_{1 j i} \cdot n_{j i} \cdot N_{0 j}^{\text {sun }} \cdot\left(1-\beta_{n j}\right)^{T}}
$$

середньодобові за період $T$ діб бойових дій відносні втрати $\beta_{n p i}$ бойових засобів $i$-го типу противника внаслідок впливу на них 3 боку всіх бойових засобів протиборчих військ для досягнення ними значення $\theta^{\text {вим }}$ визначаються згідно (3).

Таким чином, одержані основні залежності $\quad \Delta N_{n p i}=N_{0 i n p} \cdot P_{n p i}$ (7), $\Delta N_{n p}=\sum_{i} \Delta N_{n p i}=\sum_{i} P_{n p i} \cdot N_{0 i n p}(8)$, які виражені через імовірність $P_{n p i}=\frac{\Delta N_{n p i}}{N_{0 i n p}}=\beta_{n p i} \cdot T$ (5), (6) знищення силами та засобами усіх типів своїх військ в од, а також через імовірність $P_{j i}=\frac{\Delta N_{n p} j i}{N_{0 i n p}}=$ знищення $j$-ми бойовими засобами у складі $N_{0 j}$ од. своїх військ в операції тривалістю $T$ діб хоча б одного бойового засобу $i$-го типу противника з наявних $N_{0 i n p}$ од.

Для одержання більш гарантованого значення $N_{0}^{\text {вим }}$ відносно $N_{0}$ можна в $P_{j i}=\frac{\Delta N_{n p j i}}{N_{0 i n p}}$ прийняти $\beta_{n p i}$ (3), тому $P_{j i}=\frac{\Delta N_{n p j i}}{N_{0 i n p}}$ запишеться таким чином: операції тривалістю $T$ діб одного бойового засобу $i$-го типу противника з наявних $N_{0 i n p}$

$$
P_{j i}=\frac{\Delta N_{n p j i}}{N_{0 i n p}}=1-e^{-\frac{N_{0 j p}^{s u u}}{N_{0 i n p}} \cdot R_{1 j i} \cdot n_{j i} \cdot\left(1-\beta_{n j}\right)^{T}}=1-e^{-\frac{R_{1 j i} \cdot n_{j i}}{\alpha_{j i}} \cdot\left(1-\beta_{n j}\right)^{T}}
$$

де $a_{j i}=\frac{N_{0 i}}{N_{0 j p}^{\text {Buм }}}-$ співвідношення БП протиборчих сторін за $i$-ми та $j$-ми бойовими засобами. Тоді (9) набуде вигляду:

$$
\begin{aligned}
& P_{n p i}=1-\prod_{j=1}^{r}\left(1-P_{j i}\right)=1-\prod_{j=1}^{r} e^{-\frac{R_{1 j i} \cdot n_{j i} \cdot N_{0 j}^{\text {suu. }} \cdot\left(1-\beta_{n j}\right)^{T}}{N_{o i n}}}= \\
& =1-e^{-\frac{1}{N_{0 i n p}} \cdot \sum_{j=1}^{r} R_{1 j i} \cdot n_{j i} \cdot N_{0 j}^{\text {sun }} \cdot\left(1-\beta_{n j}\right)^{T}} .
\end{aligned}
$$

При цьому, обчислення $\Delta N_{n p i}$, $\Delta N_{n p}$ здійснюється, як було показано в (11), (12), лише на основі власних параметрів $\left(R_{1 j i} \cdot n_{j i}=k_{j i} \cdot T\right) \quad$ реальних бойових засобів певних типів своїх військ.

Висновки. Таким чином, запропонована математична модель (8) є однією з ключових у загальному алгоритмі проведення обчислень. Ця модель дає змогу визначити потрібну кількість бойових засобів противника, яку необхідно знищити для досягнення заданої величини відверненого збитку своїх військ та забезпечення потрібного рівня їх боєздатності $\theta^{\text {вим }}$ в операції тривалістю $T$ діб.
Такий підхід дасть змогу досягти кінцевої мети дослідження - обгрунтувати раціональний (оптимальний) бойовий склад 3 С України через величину відверненого збитку своїх військ (сил) в операції.

\section{СПИСОК ВИКОРИСТАНОЇ ЛІТЕРАТУРИ}

1. Романченко I. C. Методологічні аспекти обгрунтування бойового складу військ в операціях 3 позиції запобіжного збитку цих військ [Текст] / I. С. Романченко, В. О. Шуєнкін, B. М. Можаровський // 3б. наук. пр. “Труди університету" НУО України імені Івана Черняховського. - К., 2016. - № 2(68). - С. 279297.

2. Романченко I. С. Математична модель визначення ймовірності знищення бойовими засобами своїх військ хоча б одного бойового засобу противника 
без урахування можливих втрат початкового бойового потенціалу своїх військ і противника [Текст] / І. С. Романченко, В. М. Можаровський // 3б. наук. пр. “Труди університету” НУО України ім. Івана Черняховського. - К., 2016. - № 6(139). - С. 265-283.

3. Можаровський В. М. Математична модель визначення величини можливих втрат бойового потенціалу своїх військ за добами операції тривалістю $T$ діб [Текст] / В. М. Можаровський, С. В. Годзь // Зб. наук. пр. ХНУПС ім. Івана Кожедуба. - К., 2016. - Вип. 4 (49).- С. - С. 23 27.

4. Можаровський В. М. Математична модель визначення величини можливих втрат бойового потенціалу військ противника за добами операції тривалістю Т діб / В. М. Можаровський // Зб. наук. пр. “Труди університету” НУО України ім. Івана Черняховського. - К., 2016. - № 6(139). - С. 285297.
5. Можаровський В. М. Математична модель визначення ймовірності знищення бойовими засобами своїх військ хоча б одного бойового засобу противника з урахуванням можливих втрат початкового бойового потенціалу своїх військ та противника [Текст] / В. М. Можаровський, С. В. Годзь // Зб. наук. пр. ХНУПС імені Івана Кожедуба. - Х., 2017. - № 1(140). - С. 250-265.

6. Методика оперативно-тактических (тактических) расчетов при планировании огневого поражения противника РВ и А в операции (бою [Текст] : учеб. пос. - Кн. IV. - М.: МO СССР, упр. РВ и А СВ, 1991.$170 \mathrm{c}$.

7. Оганесов А. А. Оценка эффективности стрельбы артиллерии [Текст]: учеб. пос. / А. А. Оганесов. Л.: ВАА, 1989. - 100 с.

8. Буравлев А. И. Влияние заданных значений ущерба и собственных потерь на решение боевых задач [Текст]: учеб. пос. / А. И. Буравлев, И. П. Русанов // Воен. мысль. - 2011. - №1. - С. 26-30.

Стаття надійшла до редакції 02.02.2017

Романченко И. С., Д.воен.н., професор;

Можаровский В. Н., к.воен.н.

Центральный научно-исследовательский институт Вооружённых Сил Украины, Киев

Математическая модель определения необходимого количества уничтоженных боевых средств для достижения заданной величины предотвращенного ущерба своих войск в операции продолжительностью $T$ суток

Резюме. Раскрыто содержание одной из математических моделей, которая используется для обоснования рационального (оптимального) боевого состава Вооружённых Сил Украины через величину предотвращенного ущерба своих войск в операции (боевых действиях).

Ключевые слова: модель, вероятность, боевые средства, боевой потенциал, потери, предотвращенный ущерб.

\section{Romanchenko, Ds.M, Professor; \\ V. Mozharovsky, Ph.D}

Central Research Institute of the Armed Forces of Ukraine, Kyiv

Mathematical model of determination of necessary quantity of the enemy's destroyed fighting means for achievement of the set measure of the prevented damage of troops in an operation which duration is $T$ days

Resume. In the article the essence of a Mathematical Model is shown. The Model is used for substantiation of rational (optimum) combat staff of the Armed Forces of Ukraine through the measure of their prevented damage in operations (combat activities).

Keywords: a model, probability, fighting means, fighting potential, losses, prevented damage. 